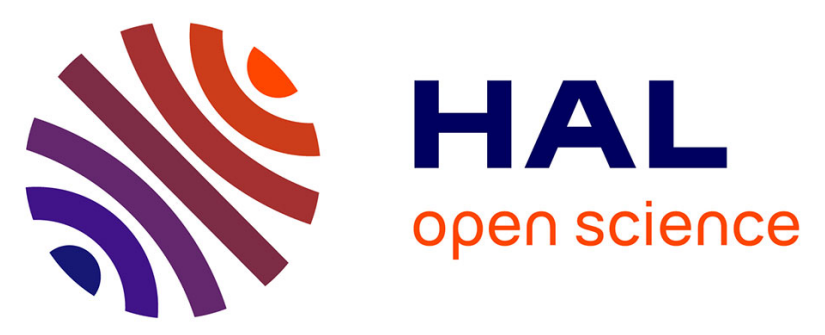

\title{
Two-year abatacept retention rate in clinical practice in the French ACTION cohort
}

Xavier Mariette, Thierry Schaeverbeke, Philippe Gaudin, Mélanie Chartier, Julia Heitzmann, Virginie Vannier-Moreau, Pascal Hilliquin, Alain Cantagrel

\section{- To cite this version:}

Xavier Mariette, Thierry Schaeverbeke, Philippe Gaudin, Mélanie Chartier, Julia Heitzmann, et al.. Two-year abatacept retention rate in clinical practice in the French ACTION cohort. Joint Bone Spine, 2019, 86 (6), pp.753 - 759. 10.1016/j.jbspin.2019.07.006 . hal-03489017

\section{HAL Id: hal-03489017 https://hal.science/hal-03489017}

Submitted on 21 Dec 2021

HAL is a multi-disciplinary open access archive for the deposit and dissemination of scientific research documents, whether they are published or not. The documents may come from teaching and research institutions in France or abroad, or from public or private research centers.
L'archive ouverte pluridisciplinaire HAL, est destinée au dépôt et à la diffusion de documents scientifiques de niveau recherche, publiés ou non, émanant des établissements d'enseignement et de recherche français ou étrangers, des laboratoires publics ou privés.

\section{()ㅜ(1)}

Distributed under a Creative Commons Attribution - NonCommercial| 4.0 International 


\section{Two-Year Abatacept Retention Rate in Clinical Practice in the French ACTION Cohort}

Xavier Mariette $^{\mathrm{a}^{*}}$, Thierry Schaeverbeke ${ }^{\mathrm{g}}$, Philippe Gaudin ${ }^{\mathrm{d}, \mathrm{e}}$, Mélanie Chartier ${ }^{\mathrm{h}}$, Julia Heitzmann ${ }^{\mathrm{i}}$, Virginie Vannier-Moreau ${ }^{\mathrm{j}}$, Pascal Hilliquin ${ }^{\mathrm{f}}$, Alain Cantagrel ${ }^{\mathrm{b}, \mathrm{c}}$

a Université Paris-Sud, AP-HP, Hôpitaux universitaires Paris-Sud, INSERM UMR1184, 94270 Le Kremlin-Bicêtre, France

${ }^{\mathrm{b} C e n t r e ~ d e ~ r h u m a t o l o g i e, ~ h o ̂ p i t a l ~ P i e r r e-P a u l-R i q u e t, ~ C H U ~ d e ~ T o u l o u s e, ~ p l a c e ~ d u ~ D r ~ B a y l a c, ~}$ TSA 40 031, 31059 Toulouse cedex 9, France

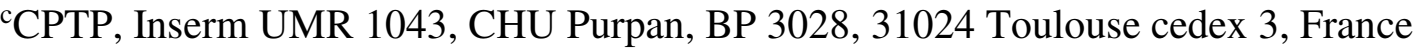

${ }^{\text {d} D e ́ p a r t e m e n t ~ d e ~ r h u m a t o l o g i e, ~ H o ̂ p i t a l ~ S u d, ~ C H U ~ d e ~ G r e n o b l e, ~} 38130$ Echirolles, France eGREPI - UGA EA 7408, Domaine de la Merci, 38700 La Tronche, France

fDépartement de rhumatologie, Centre Hospitalier Sud Francilien, 91100 Corbeil-Essonnes, France

gDépartement de rhumatologie, Hôpital Pellegrin, place Amélie Raba-Léon, 33000 Bordeaux, France

hépartement « Global Clinical Trial Strategy \& Operations », Bristol-Myers Squibb, 92500 Rueil-Malmaison, France

${ }^{i}$ Excelya, 92100 Boulogne-Billancourt, France

jMédical ImmunoScience / Rhumatologie, Bristol-Myers Squibb, 92500 Rueil-Malmaison, France

*Corresponding author: X Mariette, 78 rue du Général Leclerc, 94270 Le Kremlin-Bicêtre, France

Tel.: +33 145213758

E-mail: xavier.mariette@aphp.fr 


\section{ABSTRACT}

Objectives: Abatacept retention rates were evaluated in the French cohort in the prospective ACTION study (2010-2013), which included patients with moderate-to-severe rheumatoid arthritis managed in everyday clinical practice and started on intravenous abatacept therapy. Methods: Two-year abatacept retention rates were evaluated in 455 patients classified according to treatment line, body mass index (BMI), and status for rheumatoid factor (RF) and anti-citrullinated peptide antibody (ACPA).

Results: After 2 years, the overall abatacept retention rate was $44 \%$. The retention rate was nonsignificantly higher in the patients with vs. without a history of unresponsiveness to at least one biologic ( $48.1 \%$ vs. $41.8 \%$, respectively). No significant retention rate differences were found across BMI categories (444 patients; $<25,45.5 \%$; $\geq 25$ to $<30,48.9 \%$; and $\geq 30$, 36.6\%). Neither were any significant differences demonstrated according to RF and ACPA status (RF+ and ACPA+, 45.7\%; RF+ or ACPA+, 43.8\%; and FR- and ACPA-, 39.1\%).

Conclusion: The 44\% 2-year retention rate in the French ACTION cohort supports the usefulness of abatacept therapy. In this study, retention was not associated with treatment line, BMI, or antibody status.

Keywords: Abatacept. Biologic. Real-life study. Drug retention rate. Rheumatoid arthritis. National specificity. 


\section{Introduction}

Rheumatoid arthritis (RA) is the most common inflammatory joint disease in adults [1]. The large strides made over the past 15 years in the management of RA include the optimization of conventional synthetic disease-modifying antirheumatic drug (csDMARD) therapy, licensing of biologic agents, parsimonious use of glucocorticoids, and development of strategies that combine several drug classes.

The recommendations for the management of RA issued by the EULAR [2] and the 2018 updated guidelines of the French Society for Rheumatology (Société Française de Rhumatologie) [3] indicate that DMARD therapy should be initiated early, starting with methotrexate alone or, if needed, combined with a brief course of glucocorticoid therapy [3]. If methotrexate is inadequately effective or poorly tolerated, targeted treatments are in order in patients with adverse prognostic factors [3] such as early erosions; positive tests for rheumatoid factor (RF) and/or anti-citrullinated peptide antibodies (ACPAs), particularly in high titers $(\geq 3 \mathrm{~N})$; persistent moderate-to-high disease activity with high erythrocyte sedimentation rate (ESR) and C-reactive protein values and/or high tender and swollen joint counts despite csDMARD therapy; and failure of two or more csDMARDs $[3,4,5]$. The presence of comorbidities and preferences of the patient also influence the treatment decisions [3].

All the available biologic DMARDs (bDMARDs) have been proven to alleviate the symptoms and to slow structural disease progression in patients with RA who have an inadequate response to methotrexate. However, among patients given TNF $\alpha$ antagonist therapy, $30 \%$ to $50 \%$ stop the treatment within 1 year, due to either poor tolerance or inefficacy [6]. Many of these patients are then given a different bDMARD, which produces 
improvements in $60 \%$ to $70 \%$ of cases. The bDMARD retention rate decreases gradually as the number of previous bDMARDs used increases.

Abatacept in its intravenous formulation was approved in Europe in May 2007 for the treatment of adults with moderate-to-severe RA and an inadequate response to one or more TNF $\alpha$ antagonists. In July 2010, the approved indication was extended to include methotrexate failure or intolerance. A subcutaneous abatacept formulation was introduced in 2014 after it was found non-inferior to intravenous abatacept [7].

The drug retention rate is a simple parameter that reflects treatment efficacy and tolerance. Only observational studies and real-life registries can provide information on drug retention rates. Prospective registries have been set up in several countries to evaluate the retention rate of abatacept, such as the ORA in France (2008-2010) [8] and the pan-European registry collaboration for abatacept (PANABA) [9].

To complement these registry data, the international prospective observational study ACTION (AbataCepT In rOutiNe clinical practice) was conducted in Europe and Canada in 2008-2015 [10]. Under real-life treatment conditions, the overall 2-year abatacept retention rate was $47.9 \%$ (95\% confidence interval [95\%CI], 45.7\%-50.0\%). Retention was significantly higher in bDMARD-naive patients than in patients having failed at least one bDMARD (54.5\% [95\%CI, 50.5\%-58.3\%] vs. 45.2\% [95\%CI, 42.7\%-47.7\%], respectively; $P<0.001)[11]$.

Here, we examined the data from the patients included into the ACTION study in France with the objectives of identifying possible country-specific features of abatacept retention and of describing the treatment regimens used in everyday clinical practice. Patient inclusion into the ACTION study in France occurred after the French ORA registry was closed, and the present study therefore adds to the information available from other French nationwide investigations. 


\section{Methods}

\section{Study design and population}

ACTION (NCT02109666) was a 2-year prospective international observational study conducted in 11 European countries (Austria, Belgium, the Czech Republic, Denmark, France, Germany, Greece, Italy, The Netherlands, Spain, and Switzerland) and Canada. The objective was to assess the 2-year abatacept retention rate under the conditions of everyday practice. Inclusion criteria were age above 18 years, fulfillment of revised 1987 ACR criteria for moderate-to-severe RA, and initiation within the past 3 months of intravenous abatacept therapy in compliance with local marketing authorizations. The only non-inclusion criterion was simultaneous participation in another clinical study.

Changes in the approved indications of abatacept therapy in the participating countries during the patient recruitment period led to the differentiation of three cohorts, as follows: patients naive to bDMARD therapy or having failed at least one bDMARD ( Cohort A, May 2008-December 2010), patients naive to bDMARD therapy (cohort B, September 2010December 2013), and patients having failed at least one bDMARD (ohort C, October 2011December 2013)

The patients were followed-up for 2 years or for 6 months after abatacept discontinuation. Mean follow-up was 460 days. Data collection was stopped on January 25, 2016. No patients were included into the cohort A in France, as the ORA registry was open at the time. The 2-year abatacept retention rates were evaluated in the overall population and in the subgroups defined by treatment line (i.e., B vs C), body mass index category (BMI; <25 $\mathrm{kg} / \mathrm{m}^{2}, 25-30 \mathrm{~kg} / \mathrm{m}^{2}$, or $\left.\geq 30 \mathrm{~kg} / \mathrm{m}^{2}\right)$, and antibody status category $(\mathrm{RF}+$ and ACPA+, RF+ or 
$\mathrm{ACPA}+$, and RF- and ACPA-). In addition, comorbidities were collected by completion of a box for additional information and a predefined list of health conditions.

\section{Statistical analysis}

\section{Abatacept retention rate}

Abatacept retention after 2 years was defined as continuous abatacept therapy (via the subcutaneous or intravenous route) for 2 years. Reasons for abatacept discontinuation included primary and secondary inefficacy and any other reasons. Switching from the intravenous to the subcutaneous route was not classified as discontinuation. The nonparametric Kaplan-Meier method was applied to assess treatment duration with its 95\% confidence interval $(95 \% \mathrm{CI})$ in the overall population. Abatacept treatment duration was defined as the time between the first abatacept infusion date +1 day and the date of a reported event, such as death, date of last contact or date of last FU available). Abatacept discontinuation was defined as a period of more than 84 days without an abatacept dose, i.e., as missing two consecutive intravenous infusions, regardless of whether abatacept therapy was re-started subsequently. In a sensitivity analysis, patients who resumed abatacept therapy within 6 months after at least 84 days without a dose were classified as having continued their abatacept therapy. As observed data were analyzed, withoutimputation for missing data.

\section{Efficacy}

The 2-year clinical response rate to abatacept was evaluated in each subgroup using the EULAR criteria based on the Disease Activity Score on 28 joints (DAS 28). Patients were categorized as good responders, moderate responders, or nonresponders. Remission was defined according to the EULAR criteria as a DAS 28 (ESR or CRP) $<2.6$ or a DAS $44<1.6$ or a Simple Disease Activity Index (SDAI) $\leq 3.3$ or a Clinical Disease Activity Index (CDAI) $\leq 2.8$ or presence of the Boolean remission criteria. 
Safety

During this observational study, all serious adverse events that occurred during followup were collected until the study completion date.

\section{Results}

\section{Baseline patient Characteristics}

Of the 456 patients included by 77 rheumatologists in France, 455 were assessable (Figure 1), including 153 (33.6\%) naive to bDMARDs (cohort B) and 302 (66.4\%) having failed at least one bDMARD (cohort $\mathrm{C}$ ). Mean age was $61.7 \pm 11.8$ years in the cohort $\mathrm{B}$ and $58 \pm 12.2$ years in the cohort $\mathrm{C}$. In both cohorts, over $70 \%$ of patients were female. The BMI was available for $444(97.6 \%)$ patients, of whom over half were in the overweight or obesity range $(30.9 \%$ and $21.7 \%$ of B-cohort patients and $32.5 \%$ and $23.6 \%$ of $\mathrm{C}$-cohort patients, respectively). Of the 390 patients whose RF and ACPA status was available, 277 (71\%) were $\mathrm{RF}+$ and $\mathrm{ACPA}+, 46(12 \%)$ were $\mathrm{RF}+$ or ACPA+, and 67 (17\%) were RF- and ACPA-.

In the cohort $B$, mean disease duration was $9.4 \pm 10.5$ years, and $92.8 \%$ of patients had previously taken methotrexate. At abatacept initiation, $16.9 \%$ of patients were taking a csDMARD (other than methotrexate) and $67.3 \%$ a glucocorticoid. The cohort $\mathrm{C}$ had a longer mean disease duration of $13.8 \pm 9.9$ years and a mean number of previous csDMARDs of $1.3 \pm 1.1$ per patient, with $94.4 \%$ of patients having taken methotrexate; $46.7 \%$ and $53.3 \%$ having taken one and two TNF $\alpha$ antagonists, respectively; and $84.8 \%$ having received a glucocorticoid (Table 1). The reason for discontinuation of the most recent treatment was primary inefficacy in $25.5 \%$, secondary inefficacy in $44.0 \%$, and adverse effects in $26.8 \%$ of patients. 


\section{Treatment regimens}

Abatacept was used as single-drug therapy in $15 \%$ of cohort B and $27.2 \%$ of cohort C patients. Corresponding proportions of patients given abatacept in combination with other drugs were $85 \%$ and $72.8 \%$, respectively. Glucocorticoid therapy was given concomitantly to $67.3 \%$ of cohort $\mathrm{B}$ and $65.6 \%$ of cohort $\mathrm{C}$ patients, in a mean daily dosage of $5 \mathrm{mg}$.

Comorbidities in the cohort B and C , respectively, were as follows: smoking, $19 \%$ and 19.2\%; chronic obstructive pulmonary disease, $9.2 \%$ and $11.9 \%$; cardiovascular disease, $8.5 \%$ and $8.6 \%$; psychiatric disorders, $2 \%$ and $4.3 \%$; neurological disorders, $2.6 \%$ and $3.3 \%$; and malignancies, $2.6 \%$ and $1.3 \%$ ) (Table 1).

\section{Two-year abatacept retention rate}

After 2 years, 83/455 (18\%) patients had been lost to follow-up, leaving 372 patients for the analysis. The overall 2-year abatacept retention rate was $44.0 \%$ (95\%CI, 39.2\%-48.8\%). The 2-year retention rate was nonsignificantly higher in the cohort B than in the cohort C (48.1\% [95\%CI, 39.8\%-56.0\%] vs. $41.8 \%$ [95\%CI, 35.8\%-47.7\%]; log rank test, $P=0.22$ )

\section{(Figure 2).}

The reasons for abatacept discontinuation were similar in the two cohorts. Inadequate efficacy was the reason for discontinuation in $63.3 \%$ of cohort B patients and $68.5 \%$ of cohort $\mathrm{C}$ patients; corresponding proportions for discontinuation due to adverse events were $16.3 \%$ and $17.6 \%$.

A period longer than 84 days without an abatacept dose was recorded for 57 cohort Bpatients and 107 cohort $\mathrm{C}$ patients, who were classified as having discontinued abatacept therapy in the per protocol analysis. Among these patients, the proportion with abatacept treatment resumption within 6 months was higher in the cohort B than in the cohort C $(27 / 57$, $47.4 \%$ and $41 / 107,38.3 \%$, respectively). In the sensitivity analysis, these patients who 
resumed treatment within 6 months were not classified as having discontinued abatacept therapy. The 2-year abatacept retention rates were then $67.2 \%(95 \% \mathrm{CI}, 59.0 \%-74.2 \%)$ in the cohort B and $62.3 \%(95 \% \mathrm{CI}, 56.2 \%-68.4 \%)$ in the cohort C (Figure 2). Table 2 reports the main features of these patients at abatacept interruption and resumption. At resumption, 37\% of patients had CDAI values indicating low disease activity or remission compared to $46.2 \%$ at the last evaluation preceding the interruption; corresponding proportions of patients with DAS 28 values indicating low disease activity were $10.3 \%$ and $18.4 \%$, respectively. The proportions of patients also taking glucocorticoid therapy were higher at abatacept resumption than at the last evaluation preceding the interruption (51.5\% and $57.4 \%$, respectively).

\section{Subgroup analyses of the 2-year treatment response and retention rates}

The treatment response was similar in the cohort $\mathrm{B}$ and cohort $\mathrm{C}$ patients still taking abatacept therapy after 2 years, with good-to-moderate EULAR response rates of $90.9 \%$ vs. $78.6 \%$, respectively $(P=0.08)$. The proportions of patients in remission, defined as DAS 28 ESR and DAS 28-CRP values $<2.6$ and as meeting Boolean remission criteria (Table 3), were also similar in the two groups (DAS 28-ESR: $50.0 \%$ and $45.2 \%, P=0.64$; DAS 28-CRP: $55.4 \%$ and $58.1 \% ; P=0.64$; Boolean criteria: $25.0 \%$ and $28.4 \%, P=0.593$ ).

In the 444 patients with available BMI data, 2-year abatacept retention rates were as follows: $<25 \mathrm{~kg} / \mathrm{m}^{2}, 45.5 \%$ (95\%CI, 38.1\%-52.6\%); overweight, $48.9 \%$ (95\%CI, 39.9\%$57.2 \%)$; and obese, $36.3 \%(95 \% \mathrm{CI}, 26.7 \%-46.0 \%)$. The differences across the three subgroups were not statistically significant $(P=0.147)$.

In the 390 patients for whom RF and ACPA data obtained before abatacept initiation were available, 2-year abatacept retention rates were not significantly different across antibody status subgroups $(P=0.418): \mathrm{RF}+$ and $\mathrm{ACPA}+, 45.7 \%(95 \% \mathrm{CI}, 39.5 \%-51.8 \%)$; RF+ 
or ACPA+, 43.8\% (95\%CI, 28.3\%-58.3\%); and RF- and ACPA-, 39.1\% (95\%CI, 26.8\%$51.2 \%)$

\section{Safety data}

During the study period, severe infections were diagnosed in $28(6 \%)$ patients, including 3 opportunistic infections (1 case each of Pneumocystis jirovecii infection, candidiasis, and herpes zoster infection). In addition, 13 (3\%) patients experienced immunerelated disorders (psoriasis, $\mathrm{n}=3$; and hypersensitivity reactions, $\mathrm{n}=7), 7(1.5 \%)$ cardiac events, $5(1 \%)$ vascular events, and $5(1 \%)$ cancer. Finally, 4 (0.9\%) patients died (1 case each of acute respiratory distress, cardiac arrest, and myocardial infarction; the cause of death was not recorded in the remaining patient).

\section{Discussion}

In France, patients were included into the ACTION study between September 2010 and December 2013. The results in this country-specific cohort can be compared to the reported overall data [11-13]. The $44.0 \%$ retention rate in France was similar to the $47.9 \%$ rate internationally. Depending on the study subgroups, the retention rates in the cohort $\mathrm{C}$ patients were also similar in France and internationally (41.8\% vs. $45.2 \%$, respectively).

In France, abatacept retention rates have also been evaluated in the ORA registry of patients started on the drug between January 2007 and October 2010. The 2-year retention rate in ORA registry F-cohort patients was $42.5 \%$, which was similar to the $41.8 \%$ value in French ACTION cohort C patients [14]. 
The 2-year abatacept retention rates in the ACTION study in France were similar to those in Germany but lower than those in the cohorts B from Austria (68.5\%), Italy (67.8\%), and Switzerland (64.8\%) and in the cohorts C from Austria (58.0\%) and Italy (54.8\%) [11]. Retention rate differences across cohorts B may be related to differences in disease duration and severity in the patients included in France, who had a 2-year longer mean disease duration compared to the international population, as well as a higher mean disease activity level (SDAI, 29.1 vs. 25.4). In the cohort C, in contrast, disease activity in France was lower than internationally (SDAI, 27.2 vs. 31.9). Another possible explanation to the retention rate differences in the cohorts B and C across European countries -- and more specifically between France and Germany on one hand and Austria, Italy, and Switzerland on the other - lies in the existence of intrinsic features of each country [9]. Thus, multivariate analyses of data from the international PANABA cohort identified associations linking retention rate differences across countries to differences in access to bDMARDs, gross domestic product, clinician perceptions, and propensity of clinicians to switch among bDMARDs. Nevertheless, in the PANABA study, inefficacy and adverse events as reasons for abatacept discontinuation were more common in the registries from France (ORA), Sweden (ARTIS), and Switzerland (SQCM). Predictors of discontinuation due to inefficacy were a higher number of previous DMARDs, younger age, worse DAS 28 at abatacept initiation, and RF- status. A higher number of previous DMARDs and older age predicted discontinuation due to adverse events.

Use of bDMARDs other than TNF $\alpha$ antagonists may also affect retention rates and drug switching. A pharmaco-epidemiological study of data from a Danish and Swedish registry suggests that patients who fail a first TNF $\alpha$ antagonist should be switched to a bDMARD that has another mechanism of action, as opposed to a second TNF $\alpha$ antagonist [15]. Similarly, in a noninterventional retrospective study of data collected between 2010 and 2013 in Germany in patients having failed a first TNF $\alpha$ antagonist, 1-year retention rates were significantly 
higher when the second bDMARD was not a TNF $\alpha$ antagonist [16]. Finally, in the French ROC randomized controlled trial of patients comparing a second TNF $\alpha$ antagonist to a non$\mathrm{TNF} \alpha$ antagonist bDMARD after failure of a first TNF $\alpha$ antagonist, low disease activity after 52 weeks was more common in the non-TNF $\alpha$ antagonist group (41\% vs. 23\%; odds ratio, 2.26; 95\%CI, 1.33-3.86; $P=0.003)[17]$.

The proportions of overweight and obese patients in the French ACTION study are consistent with those expected among patients with RA [18]. In neither the French nor the international cohorts was BMI associated with the abatacept retention rate [19]. Consistently with results of the post-hoc analysis of ACQUIRE randomized controlled trial of subcutaneous vs. intravenous abatacept: pharmacokinetic or clinical outcomes were similar across patient BMI [20].

The analysis of serological status subgroups, in contrast, evidenced differences between the French and international populations. In the ACTION study patients included in France, the 2-year retention rate in the RF+ and ACPA+ subgroup was not significantly different from that in the RF+ or ACPA+ and RF- and ACPA- subgroups (45.7\%, 43.8\%, and 39.1\%, respectively). Internationally, however, the subgroup positive for both antibodies had significantly higher 6-month and 2-year retention rates compared to the subgroup with neither antibody $[21,22]$. The absence of associations with serological status in the French cohort may be merely related to insufficient statistical power. A post hoc analysis of data from the randomized controlled AMPLE trial comparing abatacept to adalimumab showed that the response rates in both groups were significantly higher in the patients with very high ACPA titers [23]. This finding suggests that the ACPA status may be more relevant than the RF status and that the two should probably be investigated separately.

In the French ACTION study, $47.4 \%$ of cohort B and $38.3 \%$ of cohort $\mathrm{C}$ patients had an at least 84-day period without abatacept doses then resumed abatacept therapy within 6 
months. The reasons for these treatment interruptions are unclear and deserve further investigation to better delineate practice patterns and to improve the evaluation of retention rates in everyday clinical practice.

This study has the limitations inherent in investigations performed under real-life conditions, including absence of active comparisons and patient attrition over time potentially resulting in a substantial amount of missing clinical data. The abatacept treatment modalities reported here reflect everyday clinical practice in France over the inclusion period from 2010 to 2013. Practices and recommendations have changed since 2013 and, therefore, the results reported here cannot be extrapolated to subsequent periods.

In conclusion, the data from the French ACTION study confirm the therapeutic value of IV abatacept on 2-year retention rates under real-life conditions [24] in adults with moderateto-severe RA who are either naive to bDMARDs or have failed one or more bDMARDs.

\section{Acknowledgments}

Fardellone P. CHU d'Amiens - Hôpital Nord, Henry Desailly I. CHU d'Amiens - Hôpital Nord, Boumier P. Polyclinique de Picardie d'Amiens, Audran M. Hôtel-Dieu d'Angers, Levy-Weil F. CH Victor Dupouy d'Argenteuil, Moineuse C. CH d'Auch, Bossert M. CH de Belfort, Lohse A. CH de Belfort, Toussirot E. CHU Jean Minjoz de Besançon, Falgarone G. Hôpital Avicenne de Bobigny, Lequerre T. CHU de Bois Guillaume, Fain O. Hôpital Jean Verdier de Bondy, Mehsen N. CHU de Bordeaux - Groupe Hospitalier, Schaeverbeke T. CHU de Bordeaux - Groupe Hospitalier, Richez C. CHU de Bordeaux - Groupe Hospitalier, Lapuyade G. à Brive-la-Gaillarde, Courtheoux Lestrehan F. Hôpital Côte de Nacre de Caen, Lassoued S. CH Jean Rougie de Cahors, Bolla G. CH de Cannes, Cadene C. CH Antoine Gayraud de Carcassonne, Sourbier M. Hôpital Gabriel Montpied de Clermont-Ferrand, Boubrit Y. CH de Compiègne, Hilliquin P. Hôpital Gilles de Corbeil Essonnes, Nang Nlome 
Nze M. Hôpital Gilles de Corbeil Essonnes, Claude Pierre P. Hôpital Henri Mondor de

Créteil, Piroth C. Hôpital Général de Dijon, Brousse A. CH de Dole, Rouidi SA. Hôpital

Victor Jousselin de Dreux, Gilson M. CHU de Grenoble - Hôpital sud à Echirolles, Gaudin P.

CHU de Grenoble - Hôpital sud à Echirolles, Bouvet C. Millasseau E. CHI de Fréjus de

Saint-Raphaël, CHI Eure Seine d'Evreux, Cormier G. CH Départemental Les Oudairies à La

Roche-Sur-Yon, Gombert B. CH Saint-Louis à La Rochelle, Hanna M. CH de Laon, Royant

V. CH Louis Pasteur à Le Coudray, Pavy S. CH de Bicêtre à Le Kremlin Bicêtre,

Amouzougan A. CH Emile Roux à Le Puy en Velay, Lacoin-Forgues C. Hôpital Robert

Boulin à Libourne, Heraud A. Hôpital Robert Boulin à Libourne, Flipo RM. Hôpital B Roger

Salengro à Lille, Philippe P. Hôpital B Roger Salengro à Lille, Coyral D. Clinique Chenieux à

Limoges, Dufauret Lombard C. Hôpital Dupuytren à Limoges, Bonnet C. Hôpital Dupuytren

à Limoges, Martinon S. CH St Joseph et St Luc à Lyon, Fontanges E. Hôpital Edouard

Herriot à Lyon, Mugnier B. Hôpital Sainte-Marguerite à Marseille, Roth O. Fondation Hôpital

Saint Joseph à Marseille, Dunant JF. CH de Meaux, Cinquetti G. Hôpital instruction des

armées Legouest de Metz, Zarnitsky C. Hôpital Jacques Monod de Montivilliers, Fallut M.

CH de Montlucon,Pers YM. Hôpital Lapeyronie de Montpellier, Le Blay P. Hôpital

Lapeyronie de Montpellier, Maillet B. Clinique St Odilon à Moulins, Ardizzone M. Hôpital

Emile Muller à Mulhouse, Maugars Y. CHU de Nantes - Hôtel Dieu, Le Goff B. CHU de

Nantes - Hôtel Dieu, Melac-Ducamp S. CH de l'Agglomération de Nevers, Foltz V. GH Pitié

Salpetrière de Paris, Berenbaum F. Hôpital Saint-Antoine de Paris, Lambrecht I. Hôpital de la

Maison Blanche à Reims, Perdriger A. Hôpitaux sud de Rennes, Poirier JL, CH de Bourran à

Rodez, Vittecoq O. au CHU de Rouen - Hôpital de Bois Guillaume, Collet P. Hôpital Nord à

St-Priest-en-Jarez, Marotte H. Hôpital Nord à St Priest en Jarez, Sordet C. CHU de

Strasbourg, Theulin A. CHU de Strasbourg, Thomas P. Hôpital Bel Air à Thionville, Laroche

M. Hôpital Purpan de Toulouse, Maizières B. Hôpital Purpan de Toulouse, Constantin A. 
Hôpital Purpan de Toulouse, Cantagrel A. Hôpital Purpan de Toulouse, Goupille P. Hôpital Trousseau de Tours, Pauly P. CH Saint Cyr de Villeneuve-sur-Lot, Florence Mercier de Stat Process, CRO InVentiv Health Clinical.

\section{Disclosure of interests}

- Alain Cantagrel has received honoraria for occasional interventions from BMS.

- Philippe Gaudin has received honoraria for occasional interventions and research grants from BMS.

- Pascal Hilliquin has received honoraria from BMS for occasional interventions.

- Thierry Schaeverbeke has received honoraria for occasional interventions and research grants from BMS.

- Xavier Mariette has received honoraria for occasional interventions from BMS, Pfizer, Samsung, and UCB.

- Mélanie Chartier is a salaried employee of Bristol-Myers Squibb

- Virginie Vannier-Moreau is a salaried employee of Bristol-Myers Squibb

- Julia Heitzmann is a salaried employee of Excelya, a contract research organization that received funding from Bristol-Myers Squibb for this study. 


\section{References}

[1] Guillemin F, Saraux A, Guggenbuhl P, et al. Prevalence of rheumatoid arthritis in France: 2001. Ann Rheum Dis 2005;64:1427-30.

[2] Smolen JS, Landewé R, Bijlsma J, et al. EULAR recommendations for the management of rheumatoid arthritis with synthetic and biological disease-modifying antirheumatic drugs: 2016 update. Ann Rheum Dis 2017;76:960-77.

[3] Daien C, Hua C, Gaujoux-Viala C, et al. Update of French Society for Rheumatology Recommendations for Managing Rheumatoid Arthritis. Joint Bone Spine 2019;86:135-50.

[4] Vastesaeger N, Xu S, Aletaha D, St Clair EW, Smolen JS. A pilot risk model for the prediction of rapid radiographic progression in rheumatoid arthritis. Rheumatology (Oxford) 2009;48:1114-21.

[5] Saevarsdottir S, Wallin S, Seddighzadeh M, et al. Predictors of response to methotrexate in early DMARD naive rheumatoid arthritis: results from the initial open-label phase of the SWEFOT trial. Ann Rheum Dis 2011;70:469-75.

[6] Hjardem E, Østergaard M, Pødenphant J, et al. Do rheumatoid arthritis patients in clinical practice benefit from switching from infliximab to a second tumor necrosis factor alpha inhibitor? Ann Rheum Dis 2007;66:1184-89.

[7] Shiff M. Subcutaneous abatacept for the treatment of rheumatoid arthritis. Rheumatology (Oxford) 2013;52:986-97.

[8] Gottenberg JE, Ravaud P, Cantagrel A, et al. Positivity for anti-cyclic citrullinated peptide is associated with a better response to abatacept: data from the 'Orencia and Rheumatoid Arthritis' registry. Ann Rheum Dis. 2012;71:1815-9. 
[9] Finckh A, Neto D, Iannone F, et al. The impact of patient heterogeneity and socioeconomic factors on abatacept retention in rheumatoid arthritis across nine European countries. RMD Open 2015;1:e000040.

[10] Alten R, Nüßlein HG, Mariette X, et al. Baseline autoantibodies preferentially impact abatacept efficacy in patients with rheumatoid arthritis who are biologic naïve: 6-month results from a real-world, international, prospective study. RMD Open 2017;3:e000345.

[11] Alten R, Lorenz HM, Mariette X, et al. Abatacept retention rates, overall and by participating country, and prognostic factors of retention in patients with RA: 2-year results from a realworld observational study. 2017 ACR/ARHP Annual Meeting, 3-8 November, San Diego, USA, Abstract number 1468, Poster Presentation.

[12] Nüßlein HG, Alten R, Galeazzi M, et al. Real-world effectiveness of abatacept for rheumatoid arthritis treatment in European and Canadian populations: a 6-month interim analysis of the 2year, observational, prospective ACTION study. BMC Musculoskelet Disord 2014;15:14.

[13] Nüßlein HG, Alten R, Galeazzi M, et al. Efficacy and prognostic factors of treatment retention with intravenous abatacept for rheumatoid arthritis: 24-month results from an international, prospective, real-world study. Clin Exp Rheumatol 2016;34:489-99.

[14] Gottenberg JE, Morel J, Perrodeau E et al. Comparative effectiveness of rituximab, abatacept, and tocilizumab in adults with rheumatoid arthritis and inadequate response to TNF inhibitors: prospective cohort study. BMJ 2019;364:167.

[15] Jørgensen ST, Turesson C, Kapetanovic MC, et al. Is mode of action important when switching biologic monotherapy in rheumatoid arthritis? Drug adherence results from the Swedish Ssatg registry. 2015 ACR/ARHP Annual Meeting, 6-11 November, San Francisco, USA, Abstract number 437, Poster Presentation. 
[16] Wilke T, Mueller S, Lee SC, Majer I, Heisen M. Drug survival of second biological DMARD therapy in patients with rheumatoid arthritis: a retrospective non-interventional cohort analysis. BMC Musculoskelet Disord 2017;18:332.

[17] Gottenberg JE, Brocq O, Perdriger A, et al. Non-TNF-targeted biologic vs a second anti-TNF drug to treat rheumatoid arthritis in patients with insufficient response to a first anti-TNF drug: a randomized clinical trial. JAMA 2016;316:1172-80.

[18] Armstrong DJ, McCausland EM, Quinn AD, Wright GD. Obesity and cardiovascular risk factors in rheumatoid arthritis. Rheumatology (Oxford) 2006;45:782.

[19] Mariette X, Alten R, Nüßlein HG, et al. The effect of body mass index on clinical response to abatacept as a first-line biologic for rheumatoid arthritis: 6-month results from the 2-year, observational, prospective ACTION study. Joint Bone Spine 2017;84:571-76.

[20] D’Agostino MA, Alten R, Mysler E, et al. Body mass index and clinical response to intravenous or subcutaneous abatacept in patients with rheumatoid arthritis. Clin Rheumatol $2017 ; 36: 2655-65$.

[21] Alten R, Nüßlein HG, Mariette X et al. Baseline autoantibodies preferentially impact abatacept efficacy in patients with rheumatoid arthritis who are biologic naïve: 6-month results from a real-world, international, prospective study. RMD Open 2017;3:e000345.

[22] Alten R, Mariette X, Lorenz HM et al. Predictors of abatacept retention over 2 years in patients with rheumatoid arthritis: results from the real-world ACTION study. Clin Rheumatol 2019;38:1413-1424.

[23] Martin-Mola E, Balsa A, García-Vicuna R, et al. Anti-citrullinated peptide antibodies and their value for predicting responses to biologic agents: a review. Rheumatol Int 2016;36:1043-63.

[24] Sherman RE, Anderson SA, Dal Pan GJ, et al. Real-world evidence - What is it and what can it tell us? N Engl J Med 2016;375:2293-97. 
Figure 1: Flow chart of patients recruited in France

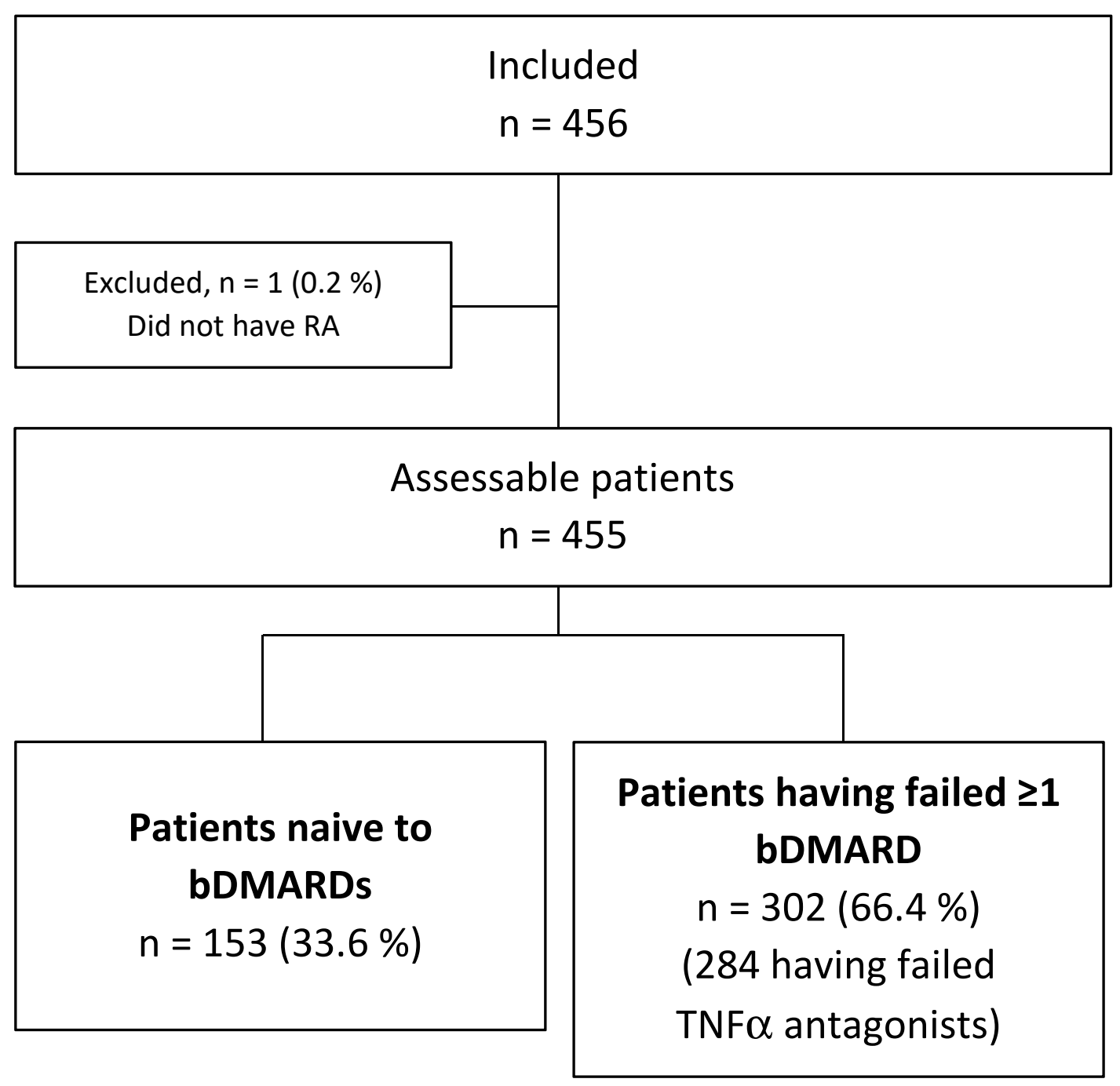


Figure 2: Two-year abatacept retention rates in the 153 patients naive to biologics and the 302 patients having failed at least one biologic, in the per protocol (solid line) and sensitivity (dashed line) analyses. In the per protocol analysis, patients who received no abatacept dose for 84 consecutive days, i.e., who missed two consecutive doses, were classified as having discontinued abatacept therapy. In the sensitivity analysis, patients who received no abatacept dose for at least 84 days but resumed abatacept therapy within 6 months were not classified as discontinuations.

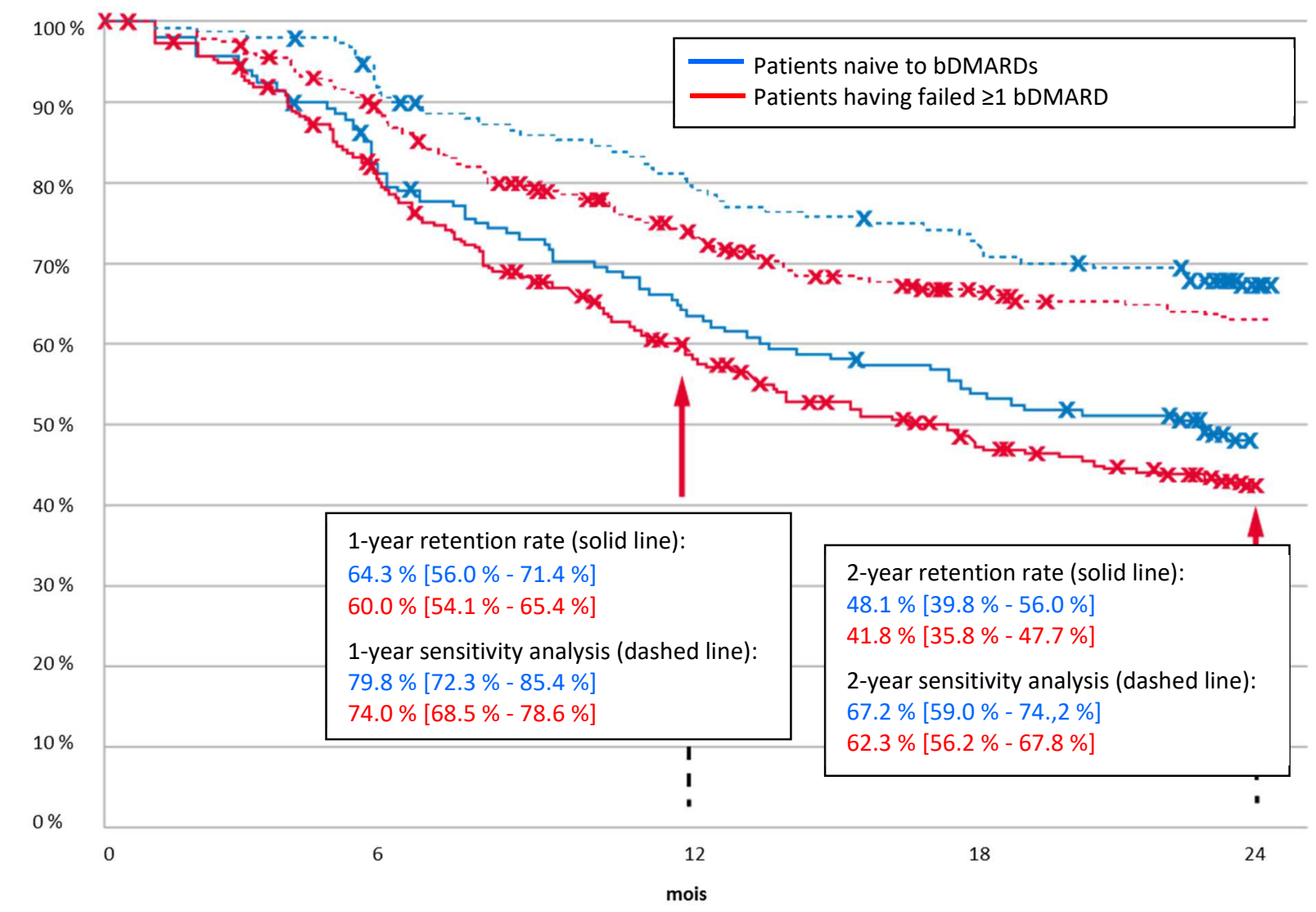

\begin{tabular}{|c|c|c|c|c|c|c|c|c|c|c|c|c|}
\hline \multirow[t]{2}{*}{$\begin{array}{l}\text { Patients } \\
\text { at risk }\end{array}$} & \multicolumn{3}{|c|}{ Month 6} & \multicolumn{3}{|c|}{ Month 12} & \multicolumn{3}{|c|}{ Month 18} & \multicolumn{3}{|c|}{ Month 24} \\
\hline & $\begin{array}{c}1^{\text {st }} \\
\text { line }\end{array}$ & $\begin{array}{c}1 \\
\text { previous } \\
\text { bDMARD }\end{array}$ & $\begin{array}{c}>1 \\
\text { bDMARDs }\end{array}$ & $\begin{array}{c}1^{\text {st }} \\
\text { line }\end{array}$ & $\begin{array}{c}1 \\
\text { previous } \\
\text { bDMARD }\end{array}$ & $\begin{array}{c}>1 \\
\text { bDMARDs }\end{array}$ & $\begin{array}{c}1^{\text {st }} \\
\text { line }\end{array}$ & $\begin{array}{c}1 \\
\text { previous } \\
\text { bDMARD }\end{array}$ & $\begin{array}{c}>1 \\
\text { bDMARDs }\end{array}$ & $\begin{array}{c}1^{\text {st }} \\
\text { line }\end{array}$ & $\begin{array}{c}1 \\
\text { previous } \\
\text { bDMARD }\end{array}$ & $\begin{array}{c}>1 \\
\text { bDMARDs }\end{array}$ \\
\hline$n$ & 124 & 80 & 161 & 94 & 54 & 109 & 82 & 41 & 85 & 50 & 23 & 40 \\
\hline
\end{tabular}


Table 1: Baseline patient characteristics in the cohort naive to biologics (cohort B) and in the cohort with failure of at least one biologic (cohort C)

\begin{tabular}{|c|c|c|c|c|}
\hline & \multicolumn{2}{|c|}{ cohort Ba } & \multicolumn{2}{|r|}{ cohort Ca } \\
\hline & $\mathrm{n}$ & & $\mathrm{n}$ & \\
\hline Age, years, mean $\pm S D$ & 153 & $61.7(11.8)$ & 302 & $58.0(12.2)$ \\
\hline Females, \% (n) & 153 & $71.2 \%(109)$ & 302 & $78.8 \%(238)$ \\
\hline $\mathrm{BMI}, \mathrm{kg} / \mathrm{m}^{2}$, mean $\pm \mathrm{SD}$ & 152 & $26.6(5.8)$ & 292 & $26.6(6.0)$ \\
\hline \multicolumn{5}{|l|}{$\mathrm{BMI}, \%(\mathrm{n})$} \\
\hline$<25 \mathrm{~kg} / \mathrm{m}^{2}$ & & $47.4 \%(72)$ & & $43.8 \%(128)$ \\
\hline $25-<30 \mathrm{~kg} / \mathrm{m}^{2}$ & & $30.9 \%(47)$ & & $32.5 \%(95)$ \\
\hline$\geq 30-<35 \mathrm{~kg} / \mathrm{m}^{2}$ & 152 & $11.8 \%(18)$ & 292 & $14.0 \%(41)$ \\
\hline$\geq 35 \mathrm{~kg} / \mathrm{m}^{2}$ & & $9.9 \%(15)$ & & $9.6 \%(28)$ \\
\hline RA duration, years, mean $\pm S D$ & 153 & $9.4(10.5)$ & 302 & $13.8(9.9)$ \\
\hline \multicolumn{5}{|l|}{ Number of previous csDMARDs ${ }^{b}$} \\
\hline mean $\pm S D$ & & $1.01(1.0)$ & 302 & $1.3(1.2)$ \\
\hline$\leq 3, \%(n)$ & 153 & $100 \%(153)$ & & $95.7 \%$ \% (289) \\
\hline$>3, \%(n)$ & & $0 \%(0)$ & & $4.3 \%(13)$ \\
\hline \multicolumn{5}{|c|}{ Number of previous TNF $\alpha$ antagonists } \\
\hline mean $\pm S D$ & & NA & & $1.61(0.81)$ \\
\hline $1, \%(n)$ & & NA & 302 & $46.7 \%(141)$ \\
\hline$\geq 2, \%(n)$ & & NA & & $53.3 \%(161)$ \\
\hline DAS 28 (ESR) & 136 & $4.8(1.2)$ & 258 & $4.9(1.3)$ \\
\hline DAS 28 (CRP) & 140 & $4.5(1.1)$ & 276 & $4.6(1.2)$ \\
\hline CDAI & 131 & $23.7(10.1)$ & 208 & $25.4(11.9)$ \\
\hline SDAI & 129 & $25.4(11.0)$ & 206 & $27.2(12.8)$ \\
\hline \multicolumn{5}{|l|}{ RF and ACPA status, $n(\%)$} \\
\hline RF- and ACPA- & & $12.4 \%(18)$ & & $17.3 \%(49)$ \\
\hline $\mathrm{RF}+$ or ACPA+ & 145 & $12.4 \%(18)$ & 283 & $9.9 \%(28)$ \\
\hline $\mathrm{RF}+$ and $\mathrm{ACPA}+$ & & $66.2 \%(96)$ & & $64.0 \%(181)$ \\
\hline unknown & & $9.0 \%(13)$ & & $8.8 \%(25)$ \\
\hline Radiographic erosion, \% (n) & 144 & $63.9 \%(92)$ & 290 & $77.2 \%(224)$ \\
\hline$\geq 1$ comorbidity, \% ( $n$ ) & & $84.3 \%$ (129) & & $74.2 \%(224)$ \\
\hline Smoking & 153 & $19.0 \%(29)$ & 302 & $19.2 \%(58)$ \\
\hline
\end{tabular}


COPD

Cardiovascular disease

BMI, body mass index; csDMARD, conventional synthetic disease-modifying antirheumatic drug; DAS 28, Disease Activity Sore on 28 joints; ESR, erythrocyte sedimentation rate; CRP, C-reactive protein; CDAI, Clinical Disease Activity Index; SDAI, Simple Disease Activity Index; RF, rheumatoid factors; ACPA, anti-citrullinated peptide antibodies; COPD, chronic obstructive pulmonary disease

${ }^{a}$ The cohort B was composed of patients naive to biologics and the cohort Bof patients having failed at least one biologic.

${ }^{\mathrm{b}}$ Other than methotrexate and glucocorticoids

\begin{abstract}
${ }^{c}$ Algebraic sum of five RA parameters (swollen joint count, tender joint count, patient evaluation of disease activity, physician assessment of disease activity, and C-reactive protein level)
\end{abstract}


Table 2: Disease activity at abatacept interruption and resumption in the patients who received no abatacept dose for at least 84 consecutive days but resumed abatacept therapy within 6 months after the last dose

\begin{tabular}{|c|c|c|}
\hline DAS 28 (ESR), mean \pm SD & $3.6(1.2)$ & $4.1(1.5)(n=58)$ \\
\hline DAS 28 low activity, \% (n) & $18.4 \%(9)$ & $10.3 \%(6)$ \\
\hline DAS 28 remission, \% (n) & $22.4 \%(11)$ & $17.2 \%(10)$ \\
\hline CDAl, mean \pm SD & $12.0(7.0)$ & $15.2(11.8)(n=46)$ \\
\hline CDAI low activity or remission, \% (n) & $46.2 \%(18)$ & $37.0 \%(n=17 / 46)$ \\
\hline EULAR response good or moderate, $\%$ ( $n$ ) & $63.3 \%(31)$ & $50.8 \%(30)(n=30 / 59)$ \\
\hline Boolean remission, \% ( $\mathrm{n}$ ) & $4.1 \%(2)$ & $11.9 \%(n=7 / 59)$ \\
\hline Concomitant treatments & $\mathrm{n}=68$ & $\mathrm{n}=68$ \\
\hline Glucocorticoid therapy, \% (n) & $51.7 \%(30)$ & $57.4 \%(39)$ \\
\hline Methotrexate, \% (n) & $62.1 \%(36)$ & $54.4 \%(37)$ \\
\hline
\end{tabular}

DAS 28, Disease Activity Score on 28 joints; ESR, erythrocyte sedimentation rate; CDAI, Clinical Disease Activity Index 
Table 3: Two-year treatment response rate (\% of responders)

\begin{tabular}{|l|c|c|c|c|c|}
\hline & \multicolumn{2}{|c|}{ cohort $^{\mathrm{a}}$} & \multicolumn{2}{|c|}{ cohort C $^{\mathrm{a}}$} & $P$ value \\
\hline & $\mathrm{n}^{\mathrm{b}}$ & $\%$ & $\mathrm{n}^{\mathrm{b}}$ & $\%$ & \\
\hline $\begin{array}{l}\text { EULAR response good } \\
\text { to moderate }\end{array}$ & 55 & $90.9 \%$ & 70 & $78.6 \%$ & 0.08 \\
\hline DAS 28 (ESR) <2.6 & 52 & $50.0 \%$ & 73 & $45.2 \%$ & 0.64 \\
\hline DAS 28 (CRP) <2.6 & 56 & $55.4 \%$ & 74 & $58.1 \%$ & 0.64 \\
\hline Boolean remission & 56 & $25.0 \%$ & 74 & $28.4 \%$ & 0.593 \\
\hline
\end{tabular}

DAS 28, Disease Activity Sore on 28 joints; ESR, erythrocyte sedimentation rate; CRP, Creactive protein

${ }^{a}$ The cohort B was composed of patients naive to biologics and the cohort Cof patients having failed at least one biologic.

${ }^{b}$ number of patients with available 2-year data 